\title{
EFEKTIVITAS KELENGKAPAN PENDOKUMENTASIAN BUKU KIA UNTUK DETEKSI RESIKO TINGGI KEHAMILAN DI PUSKESMAS WILAYAH KOTA PEKALONGAN
}

\author{
Pedvin Ratna Meikawati ${ }^{1}$, Ana Setyowati ${ }^{2}$, Ni'matul Ulya ${ }^{3}$ \\ E mail: pedvin_ratna@yahoo.com \\ DIII AKBID Harapan Ibu Pekalongan \\ Jl. Sriwijaya No. 7 Pekalongan \\ Telp/Fax (0285)4416108
}

\begin{abstract}
Abstrak
Buku Kesehatan Ibu dan Anak (KIA) merupakan bentuk peran serta aktif keluarga dan masyarakat dalam bidang kesehatan ibu dan anak. Keberhasilan penerapan buku KIA sebagai salah satu alat untuk meningkatkan cakupan pelayanan KIA tidak terlepas dari peran para pihak terkait dengan kesehatan ibu hamil, ibu bersalin, bayi baru lahir, bayi dan anak balita. Buku KIA memiliki beberapa kegunaan antara lain sebagai pedoman yang dimiliki ibu dan anak yang berisi informasi dan catatan kesehatan ibu dan anak, dan juga buku KIA berfungsi sebagai satu-satunya alat pencatatan kesehatan ibu dan anak. Penelitian ini bertujuan untuk menganalisis kelengkapan pendokumentasian data ibu hamil dari buku KIA di Puskesmas Wilayah Kota Pekalongan. Penelitian ini dilakukan dengan menggunakan metode penelitian kombinasi kuantitatif dan kualitatif (mixed methodology). Penelitian kuantitatif menggunakan metode penelitian survey (survey research method) dan pendekatan cross sectional yaitu variabel-variabelnya diukur dalam waktu bersamaan. Populasi dalam penelitian ini adalah buku KIA, sedangkan sampel dalam penelitian ini adalah bidan yang sedang berdinas di Puskesmas dengan masa kerja minimal 1 tahun dan ibu hamil yang sedang memeriksakan kehamilannya yang besarnya sampel ditentukan dengan metode incidental sampling dan purposif sampling berdasarkan puskesmas yang digunakan. Hasil uji dengan regresi logistic didapatkan nilai $\mathrm{p}$ value $<0,05$ dan nilai $\operatorname{Exp}(\mathrm{B}) \geq 2$ adalah variabel masa kerja . Variabel masa kerja dengan $\mathrm{p}$ value 0,095 , nilai Exp (B) 10,0 (OR $\geq 2)$, sedangkan variabel anamnesa tidak mempunyai $p$ value $<0,05$ yaitu dengan $p$ value 0,341, nilai Exp (B) 3,0. Sehingga dapat disimpulkan tidak ada pengaruh masa kerja dan anamnesa secara bersama-sama terhadap kelengkapan pendokumentasian buku KIA untuk deteksi dini resiko tinggi pada kehamilan. Para bidan di Puskesmas Kota Pekalongan disarankan untuk lebih meningkatkan kelengkapan pengisian buku KIA dalam deteksi dini resiko tinggi ibu hamil. Meningkatkan motivasi kepada bidan dengan cara memberi penghargaan bagi bidan yang telah melaksanakan tugasnya dengan baik.
\end{abstract}

Kata kunci: Buku KIA, Pendokumentasian, Deteksi Resiko Tinggi Ibu Hamil.

\section{Pendahuluan}

Indikator derajat kesehatan masyarakat berhubungan erat dengan Angka Kematian Ibu (AKI), Angka Kematian Bayi (AKB) yang menjadi salah satu masalah kesehatan di Indonesia untuk ditangani karena mengindikasikan kemampuan dan kualitas pelayanan kesehatan, kapasitas pelayanan kesehatan, kualitas pendidikan dan pengetahuan masyarakat, kualitas kesehatan lingkungan, sosial budaya serta hambatan dalam memperoleh akses terhadap pelayanan kesehatan (Dinkes Jateng, 2012).

Menurut Survei Demografi Kesehatan Indonesia (SDKI) tahun 2012 AKI sebesar 359 per 100.000 kelahiran hidup.2 AKI di Provinsi Jawa Tengah mengalami peningkatan secara signifikan selama tahun 2013-2014 yaitu sebesar 118,62 per 100.000 kelahiran hidup menjadi 126,55 per 100.000 kelahiran hidup (Dinkes Jateng, 2014)

Data profil Dinas Kesehatan Kota Pekalongan menunjukkan bahwa AKI pada tahun 2015 yaitu sebesar 6 kasus mengalami peningkatan menjadi 8 kasus pada tahun 2016. Adapun penyebab langsung kematian ibu adalah Eklampsia (3 kasus), perdarahan (3 kasus), emboli air ketuban (1 kasus) dan oedem pulmo (1 kasus) dan semua kasus kematian ibu terjadi di rumah sakit ( Dinkes Kota Pekalongan, 2016).

Untuk mengurangi AKI dan AKB di Indonesia, pemerintah mengeluarkan beberapa program dan upaya antara lain 
penerapan pendekatan safe methode pada tahun 1990, program Buku Kesehatan Ibu dan Anak (KIA) yang mulai di ujicobakan sejak tahun 1994, gerakan sayang ibu pada tahun 1996, Making pragnancy safer pada tahun 2000, bantuan operasional kesehatan (BOK) pada tahun 2010, jampersal yang di mulai pada tahun 2011, dan juga program expanding mathernal and neonatal safer pada tahun 2012 (Kemenkes RI, 2013).

Buku Kesehatan Ibu dan Anak (KIA) merupakan bentuk peran serta aktif keluarga da masyarakat dalam bidang kesehatan ibu dan anak. Keberhasilan penerapan buku KIA sebagai salah satu alat untuk meningkatkan cakupan pelayanan KIA tidak terlepas dari peran para pihak terkait dengan kesehatan ibu hamil, ibu bersalin, bayi baru lahir, bayi dan anak balita (Buku KIA, 2008).

Pengelolaan program KIA bertujuan memantapkan dan meningkatkan jangkauan serta mutu pelayanan KIA secara efektif dan efisien. Pemantapan pelayanan KIA dewasa ini diutamakan pada kegiatan pokok di mana salah satunya adalah peningkatan deteksi dini faktor risiko dan komplikasi kebidanan dan neonatus oleh tenaga kesehatan maupun masyarakat. Deteksi dini kehamilan dengan faktor risiko adalah kegiatan yang dilakukan untuk menemukan ibu hamil yang diduga mempunyai risiko dan komplikasi kebidanan. Kehamilan merupakan proses reproduksi yang normal, tetapi tetap mempunyai risiko untuk terjadinya komplikasi. Untuk itu deteksi dini oleh tenaga kesehatan dan masyarakat tentang adanya faktor risiko dan komplikasi, serta penanganan yang adekuat sedini mungkin, merupakan kunci keberhasilan dalam penurunan angka kematian ibu dan bayi yang dilahirkannya (Depkes, 2003).

Buku kesehatan ibu dan anak (KIA) sebagai salah satu program dan upaya pemerintah guna mengurangi AKI dan AKB merupakan hasil kerja sama Departemen Kesehatan-RI dengan Japan International Cooperation Agency (JICA). Buku KIA merupakan alat yang sederhana namun efektif sebagai alat informasi, edukasi, dan komunikasi. Oleh karena itulah pada tahun 1997
Departemen Kesehatan menggunakan model buku KIA tersebut sebagai acuan dalam pengembangan buku KIA versi nasional, dan menjadikan buku KIA sebagai program nasional (Destria, 2010).

Pengelolaan Program KIA dalam pelayanan Ante Natal Care (ANC) adalah pelayanan kesehatan oleh tenaga kesehatan untuk ibu, dilaksanakan sesuai dengan standar pelayanan Ante Natal yang ditetapkan dalam Standar Pelayanan Kebidanan (SPK). Pelayanan Ante Natal sesuai standar meliputi anamnase, pemeriksaan fisik (umum dan kebidanan), pemeriksaan laboratorium rutin dan khusus, serta intervensi umum dan khusus (sesuai resiko yang ditemukan dalam pemeriksaan) (Depkes RI, 2009).

Penggunaan buku KIA merupakan strategi pemberdayaan masyarakat terutama keluarga untuk memelihara kesehatannya dan mendapatkan pelayanan kesehatan ibu dan anak yang berkualitas. Buku KIA sebagaimana tercantum dalam keputusan Mentri Kesehatan no 284/Menkes/SK/III/2004 mengenai buku KIA memiliki beberapa kegunaan antara lain sebagai pedoman yang dimiliki ibu dan anak yang berisi informasi dan catatan kesehatan ibu dan anak, dan juga buku KIA berfungsi sebagai satu-satunya alat pencatatan kesehatan ibu dan anak, selain itu isi dari buku KIA juga berfungsi sebagai alat penyuluh Kesehatan atau pembelajaran, dan alat komunikasi kesehatan (Kepmenkes RI No 284, 2004).

\section{Metode Penelitian}

Penelitian ini dilakukan dengan menggunakan metode kombinasi kuantitatif dan kualitatif (mixed methodology). Informan dalam penelitian ini adalah bidan yang sedang berdinas di Puskesmas dengan masa kerja minimal 1 tahun dan ibu hamil yang sedang memeriksakan kehamilannya. Prosedur pengambilan subyek dalam penelitian ini sebanyak 30 bidan menggunakan cara atau metode incidental sampling dan purposif sampling berdasarkan puskesmas yang digunakan. 


\section{Hasil dan Pembahasan}

a. Karakteristik responden berdasarkan umur

\begin{tabular}{|c|c|}
\hline Umur & $\begin{array}{cc}\text { Frekue } & \text { Persentase } \\
\text { nsi } & (\%)\end{array}$ \\
\hline $20-30$ tahun & 53,3 \\
\hline $31-40$ tahun & 33,3 \\
\hline $41-50$ tahun & 13,4 \\
\hline Total & 100 \\
\hline \begin{tabular}{l}
\multicolumn{2}{c}{ Umur ad } \\
yang terhit \\
dilahirkan sar \\
tahun. Sema \\
kematangan \\
seseorang ak \\
dalam berfi \\
Menuru Rol \\
Gibson (2003 \\
bahwa semaki \\
makin ting \\
terhadap orgar \\
Karakteristik re \\
pendidikan
\end{tabular} & $\begin{array}{l}\text { lalah usia individu } \\
\text { ung mulai saat } \\
\text { mpai saat beberapa } \\
\text { kin cukup tingkat } \\
\text { dan kekuatan } \\
\text { kan lebih matang } \\
\text { kir dan bekerja. } \\
\text { oins dalam buku } \\
\text { ) yang menyatakan } \\
\text { in tua usia pegawai, } \\
\text { gi komitmennya } \\
\text { hisasi, } \\
\text { sponden berdasarkan }\end{array}$ \\
\hline Pendidikan & $\begin{array}{cc}\text { Frekuensi } & \text { Persentase } \\
(\%)\end{array}$ \\
\hline $\begin{array}{l}\text { Diploma } \\
\text { III }\end{array}$ & 80 \\
\hline $\begin{array}{l}\text { Diploma } \\
\text { IV }\end{array}$ & 20 \\
\hline Total & 100 \\
\hline
\end{tabular}

Pada penelitian ini, mayoritas responden lulusan DIII Kebidanan yang memiliki kompetensi untuk melaksanakan tugas dan kewajibannya berupa laporan secara administrasi dalam hal pencatatan data KIA. Menurut KEPMENKES No.369/MENKES/SK/III/2007

tentang Standar Profesi Bidan yaitu lulusan pendidikan D III Kebidanan, merupakan bidan pelaksana yang memiliki kompetensi melaksanakan praktiknya di institusi pelayanan maupun praktik perorangan (Depkes, 2007). Maka hal ini menunjukkan bahwa pendidikan responden sudah memenuhi standar profesi bidan yang ditetapkan baik oleh organisasi profesi maupun oleh Dinas Kesehatan.

c. Karakteristik responden berdasarkan kelengkapan anamnesa buku KIA

\begin{tabular}{|c|c|c|}
\hline $\begin{array}{c}\text { Kelengkapan } \\
\text { Anamnesa } \\
\text { Buku KIA }\end{array}$ & $\begin{array}{l}\text { Frekuen } \\
\text { si }\end{array}$ & $\begin{array}{l}\text { Persent } \\
\text { ase }(\%)\end{array}$ \\
\hline Lengkap & 21 & 70 \\
\hline $\begin{array}{c}\text { Kurang } \\
\text { Lengkap }\end{array}$ & 9 & 30 \\
\hline Total & 30 & 100 \\
\hline
\end{tabular}
wawancara antara pasien/keluarga pasien dengan tenaga kesehatan untuk memperoleh keterangan tentang keluhan dan penyakit yang diderita pasien dengan tujuan untuk mendapatkan data kesehatan dan permasalahan medis sehingga dapat menentukan perkiraan diagnose/masalah medis yang dihadapi pasien. Allport, Martin Bubes dan Carl Rogers menyatakan: Makin baik hubungan interpersonal yang terjadi, maka pasien akan makin terbuka untuk mengungkapkan perasaanya, sehingga tenaga kesehatan akan makin mengetahui problema dan penderitaan yang dihadapi pasien.

d. Karakteristik responden berdasarkan pendokumentasian buku KIA

\begin{tabular}{ccc}
\hline $\begin{array}{c}\text { Kelengkapan } \\
\text { Pendokumentasian } \\
\text { Buku KIA }\end{array}$ & $F$ & $\%$ \\
\hline Lengkap & 19 & 63,3 \\
Kurang Lengkap & 11 & 36,7 \\
\hline Jumlah & 30 & 100 \\
\hline Pendokumentasian & merupakan
\end{tabular}
unsur pokok dalam pertanggung jawaban kinerja profesi tenaga kesehatan. Catatan pasien merupakan suatu dokumen legal berbentuk tulisan,yang menggambarkan asuhan yang diberikan. Melalui dokumentasi yang dilakukan dengan baik dan benar, diharapkan asuhan yang berkualitas dapat dicapai, karena jaminan kualitas merupakan bagian dari program pengembangan pelayanan kesehatan. Suatu perbaikan tidak dapat diwujudkan tanpa dokumentasi yang kontinu, akurat dan rutin baik yang dilakukan oleh perawat/bidan maupun tenaga kesehatan lainnya. (Hidayat, 2008). 
e. Hubungan masa kerja dengan kelengkapan pendokumentasian buku KIA

\begin{tabular}{|c|c|c|c|c|}
\hline \multirow[t]{3}{*}{$\begin{array}{l}\text { Masa } \\
\text { Kerja }\end{array}$} & \multicolumn{4}{|c|}{$\begin{array}{l}\text { Pendokumentasian Buku } \\
\text { KIA }\end{array}$} \\
\hline & \multicolumn{2}{|c|}{ Lengkap } & \multicolumn{2}{|c|}{$\begin{array}{l}\text { Kurang } \\
\text { lengkap }\end{array}$} \\
\hline & $F$ & $\%$ & $F$ & $\%$ \\
\hline Lama & 15 & 71,4 & 1 & 11,1 \\
\hline Baru & 6 & 28,6 & 8 & 88,9 \\
\hline Total & 21 & 100 & 9 & 100 \\
\hline
\end{tabular}

Berdasarkan hasil analisis dengan uji Chi Square Test didapatkan $p$ value yaitu 0,002 ( $p$ value < 0,05) yang artinya $\mathrm{Ha}$ diterima dan Ho ditolak sehingga dapat disimpulkan bahwa ada hubungan antara masa kerja dengan kelengkapan pendokumentasian buku KIA untuk deteksi dini resiko tinggi pada kehamilan.

Masa kerja merupakan indikator yang dapat mempengaruhi peningkatan kemampuan keterampilan seseorang. Semakin lama masa kerja seseorang, biasanya tingkat keterampilan mengenai bidang pekerjaannya akan semakin meningkat. Masa kerja berhubungan dengan pengalaman yang didapat selama menjalankan tugas. Pengalaman kerja juga ikut menentukan kinerja seseorang (Robbins, 2006).

Sehingga dapat disimpulkan bahwa semakin lama masa kerja, cenderung melakukan pendokumentasian buku KIA untuk deteksi dini resiko tinggi pada kehamilan secara lengkap karena didukung oleh teori yang menyebutkan bahwa mereka yang berpengalaman dipandang lebih mampu dalam pelaksanaan tugas, makin lama masa kerja seseorang makin kecakapan mereka akan lebih baik, karena sudah sesuai dengan pekerjaannya (Suwarto, 2009).

f. Hubungan pendidikan denga kelengkapan pendokumentasian buku KIA

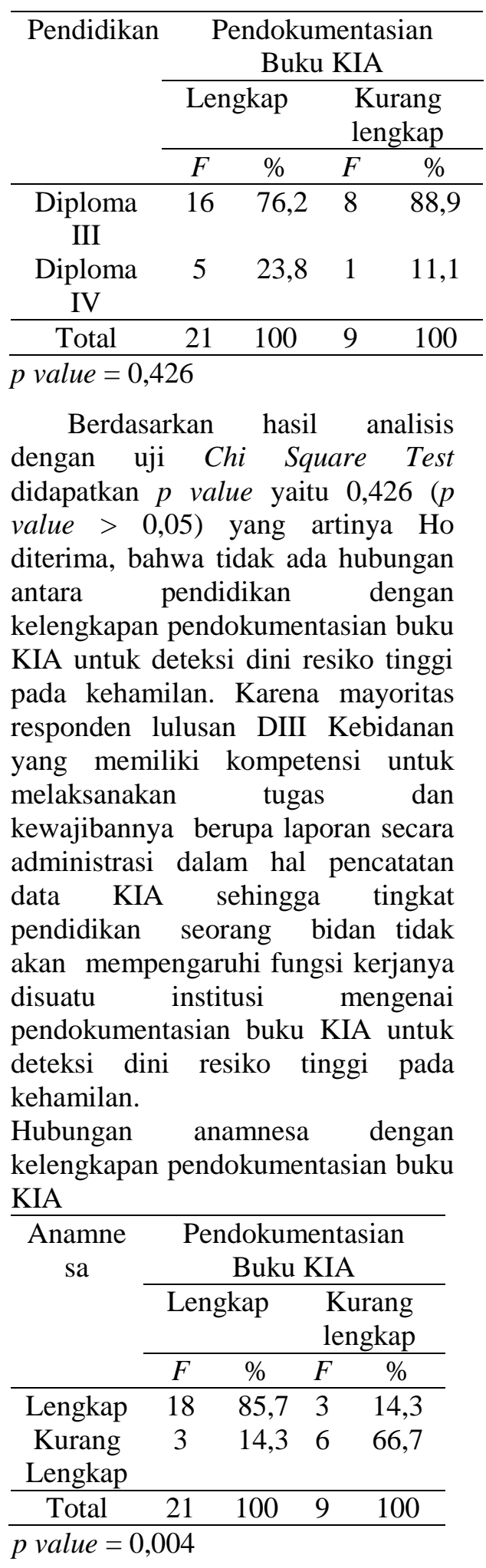

Berdasarkan hasil analisis dengan uji Chi Square Test didapatkan $p$ value yaitu 0,004 ( $p$ value < 0,05) yang artinya $\mathrm{Ha}$ diterima dan Ho ditolak sehingga dapat disimpulkan bahwa ada hubungan antara anamnesa dengan kelengkapan pendokumentasian buku 
KIA untuk deteksi dini resiko tinggi pada kehamilan.

Salah satu aspek dalam pendokumentasian adalah melakukan anamnesa terhadap pasien. Anamnesa meliputi dari identitas pasien, keluhan, riwayat kesehatan serta pole kebiasaan sehari-hari. Dan hal inilah memerlukan kesabaran dan ketelitian tenaga kesehatan. Hasil serupa juga ditunjukkan pada penelitian yang dilakukan oleh Manullang(2012), pada dasarnya bidan kurang sabar dalam mengisi buku KIA sehingga pencatatan hanya dilakukan pada bagian yang dianggap penting saja. Dan diperkuat oleh teori Mufdillah (2012) yang menyatakan pengisian buku KIA diperlukan ketelitian dan kesabaran, sehingga pendokumentasian kebidanan khususnya buku KIA dapat berjalan dengan maksimal sehingga bidan tidak kesulitan bahkan tidak salah dalam mengambil keputusan medis terhadap ibu hamil dan dapat mendeteksi secara dini jika terjadi penyulit dalam kehamilan.

h. Hasil Analisa Multivariat

\begin{tabular}{ccccccc}
\hline Variabel & B & SE & Wald & Df & $\begin{array}{c}\text { P } \\
\text { value }\end{array}$ & $\begin{array}{c}\text { Exp. } \\
\text { B }\end{array}$ \\
\hline Masa kerja & 2,3 & 1,3 & 2,790 & 1 & 0,09 & 10,0 \\
& 03 & 78 & & & 5 & \\
\hline Anamnesa & 1,0 & 1,1 & 0,905 & 1 & 0,34 & 3,0 \\
& 99 & 55 & & & 1 & \\
\hline
\end{tabular}

Variabel yang mempunyai $p$ value $<0,05$ dan nilai $\operatorname{Exp}(\mathrm{B}) \geq 2$ adalah variabel masa kerja . Variabel masa kerja dengan $\mathrm{p}$ value 0,095 , nilai $\operatorname{Exp}(\mathrm{B}) \quad 10,0 \quad(\mathrm{OR} \geq 2$ ), sedangkan variabel anamnesa tidak mempunyai $\mathrm{p}$ value $<0,05$ yaitu dengan $\mathrm{p}$ value 0,341 , nilai $\operatorname{Exp}(\mathrm{B})$ 3,0 .

Kesimpulannya adalah tidak ada pengaruh masa kerja dan anamnesa secara bersama-sama terhadap kelengkapan pendokumentasian buku KIA untuk deteksi dini resiko tinggi pada kehamilan. Bidan yang memiliki masa kerja yang lama, akan melakukan pendokumentasian yang lengkap 10,0 kali lebih besar dibanding bidan yang memiliki masa kerja yang baru.

Buku KIA disimpan oleh ibu dan harus dibawa apabila ibu akan melakukan pemeriksaan kesehatan terutama kunjungan antenatal. Sehingga apabila buku KIA tidak dibawa pada saat ibu melakukan kunjungan antenatal maka bidan tidak bisa mengisi buku KIA secara lengkap dalam deteksi dini resiko tinggi pada ibu hamil walaupun bidan telah lama bekerja dan melakukan anamnesa lengkap untuk deteksi dini resiko tinggi. Hal inilah yang menyebabkan faktor anamnesa tidak mempengaruhi efektifitas kelengkapan pendokumentasia buku KIA untuk deteksi dini resiko tinggi kehamilan.

\section{Kesimpulan}

Karakteristik responden rerata usia 31,9 tahun dengan pendidikan terbanyak Diploma III Kebidanan sebanyak 24 responden $(80 \%)$. Responden yang anamnesa buku KIA lengkap (70\%), pendokumentasian buku KIA lengkap (63,3\%). Variabel yang berhubungan dengan kelengkapan pendokumentasian Buku KIA adalah Masa Kerja ( $\rho$ value $=0,002), \quad$ pendidikan $\quad(\rho$ value $=0,426)$ dan anamnesa $(\rho$ value $=0,004)$. Variabel yang mempunyai pengaruh bersama-sama dengan kelengkapan pendokumentasian buku KIA adalah masa kerja dengan nilai $\mathrm{p}$ value $=0,095(\mathrm{p}<0,05)$.

\section{Daftar Pustaka}

[1] Bandiyah, S.2011. Kehamilan, Persalinan dan Gangguan Kehamialn dan Persalinan. Yogyakarta: Mitra Cendikia Press.

[2] Depkes RI. 2003. Buku Kesehatan Ibu dan Anak. Jakarta: Depkes RI dan JICA

[3] Depkes RI. 2015. Pedoman Pelayanan Antenatal di Tingkat Pelayanan Kesehatan Dasar. Jakarta: Balitbang;

[4] Elhooda. Buku Kesehatan Ibu dan Anak (KIA) dan KMS, dikutip (15 Januari 2016) dalam 
http://www.elhooda.com/2011/07/buku kesehatan-bu-dan-anak-kia-dan-kms/.

[5] Hidayat, A. Alimul. 2008. Dokumentasi Kebidanan. Jakarta: Salemba Medika.

[6] Ikatan Dokter Indonesia (IDI). 2005. Buku Pedoman Deteksi Dini, Pelaporan, dan Rujukan Kasus Kekerasan dan Penelantaraan Anak Bagi Tenaga kesehatan. Jakarta: IDI.

[7] Kemenkes Ri. 2013. Riset Kesehatan Dasar; RISKESDAS. Jakarta: Balitbang Kemenkes RI

[8] Kusmiyati, Yuni, 2009. Perawatan Ibu Hamil, Citra Maya, Yogyakarta;

[9] Lerner. J. W. (1998) Learning disability: Theories, diagnosis and teaching strategies. New Jersey: Houghton Mifflin Company.

[10] Mochtar, Rustam. 2012. Sinopsis Obstetri, EGC, Jakarta;

[11] Pantikawati, Ika, Saryono. 2012. Asuhan Kebidanan 1 (Kehamilan). Yogyakarta: Nuha Medika.

[12] Prawirohardjo. 2009. Ilmu Kebidanan, PT Bina Pustaka Sarwono Prawirohardjo, Jakarta;

[13] Riyanto, Agus. 2011. Aplikasi Metodologi Penelitian Kesehatan. Nuha Medika, Yogyakarta;

[14] Riwidikdo, Handoko. 2012. Statistik Kesehatan. Nuha Medika. Yogyakarta;

[15] Rochjati. P. 2003. Buku Saku Deteksi Risiko Tinggi Puji Rochyati. Surabaya.

[16] Sari, Narulita. 2013. Konsep Kebidanan, Graha Ilmu, Yogyakarta;

[17] Singarimbun M. dan Effendi S. 2003. Metodologi Penelitian Survey, LP3ES, Yogyakarta;

[18] Sugiyono. 2007. Statistika Untuk Penelitian. Alfa Betha. Bandung;

[19] Nursalam.2008. Konsep dan Penerapan Metodologi Penelitian. Jakarta: Salemba Medika

[20] Gibson, J.L. Ivancevich, J.M. Donnelly J.H. Organisasi Perilaku Struktur Proses,.8 Edisi, Jilid 2. Jakarta: Bina Rupa Aksara; 2010.

[21] Afrida. Ekonomi Sumber Daya Manusia. Jakarta: Ghalia Indonesia; 2013.
[22] Siagian S. Manajemen Sumber Daya Manusia, Edisi 1, Cetakan 8. Jakarta: Bumi Aksara; 2009.

[23] Suwarto, Fx. 2009. Perilaku Keorganisasian, Buku Panduan Mahasiswa.Yogyakarta: Universitas Atma Jaya Yogyakarta 